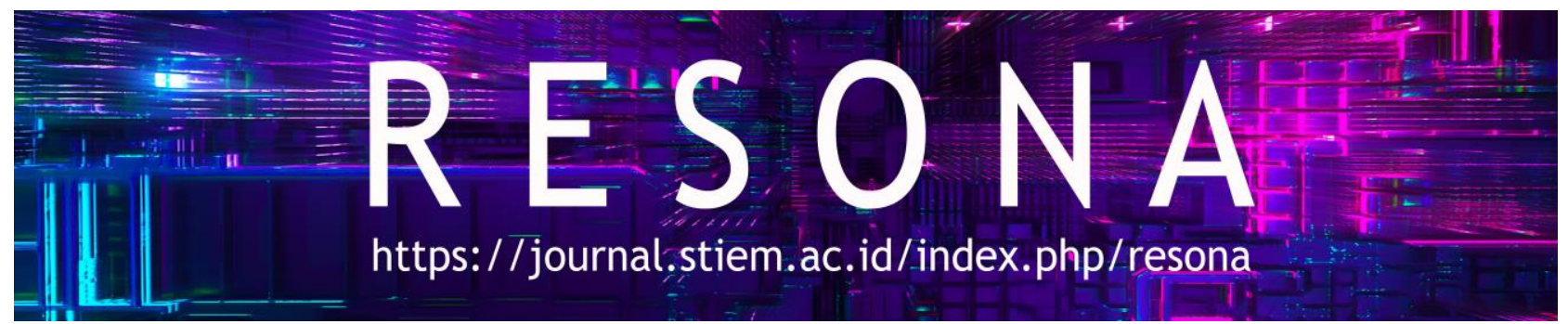

\title{
Maksimalisasi Kapasitas Produksi Dan Kualitas Batik Melalui Implementasi Canting Elektrik Pada Industri Rumah Tangga Batik Di Keluarahan Merjosari Malang
}

\author{
Adya Hermawati ${ }^{1}$, Choirul Anam ${ }^{2}$, Candra Aditya ${ }^{3}$, Dwi Anggarani ${ }^{4}$, Syamsul Bahri $^{5}$ \\ 1,2,3,4,5 Universitas Widyagama Malang
}

\begin{tabular}{l} 
INFO NASKAH \\
Diserahkan \\
28 April 2020 \\
Diterima \\
28 April 2020 \\
Diterima dan Disetujui 10 \\
Juni 2020 \\
\hline
\end{tabular}

Kata Kunci:

Program Kemitraan

Masyarakat,

Industri Rumah Tangga,

Batik Malang

Keywords:

Community Partnership

Program,

Home Industry,

Batik Malang

\section{ABSTRAK}

Motif batik malangan mempunyai makna luhur bagi penggunanya sehingga banyak dimininati oleh masyarakat luas sehingga membuka potensi peluang usaha bagi warga Malang. Potensi dan peluang bisnis pengrajin batik Malangan ini sangat prospektif, namun proses pembuatan dan pemasarannya belum optimal. Pelaksanaan Program Kemitraan Masyarakat (PKM) ini berfokus pada kelompok Pengrajin Industri Rumah Tangga (IRT) "Batik Asli Malangan" dan Pengrajin IRT "Batik Tradisional Sido Mukti". Program pengabdian masyarakat ini dilakukan untuk dapat meningkatkan jumlah produksi secara efisien dengan mentransformasi teknologi. Penambahan canting dan kompor elektrik dari pelaksanaan Program Kemitraan Masyarakat (PKM) ini menjadi salah satu upaya untuk menambah jumlah produksi secara efisien dengan mentransformasi teknologi tersebut. Dalam rangka peningkatan pengetahuan dan keterampilan pengusaha Batik Malangan Konvensional di Kelurahan Merjosari Malang dalam hal pembukuan, pemasaran hasil usaha dan pewarnaan batik diadakan pula pelatihan pembukuan, pemasaran hasil usaha dan pewarnaan batik. Pelatihan dilaksanakan disalah satu rumah warga Kelompok Batik Malangan Konvensional di Kelurahan Merjosari Malang dengan jumlah peserta 30 orang pelaku usaha.

Abstract. Malangan batik motif has a significant meaning for its users so much in demand by the broader community that it opens up potential business opportunities for the citizens of Malang. The potential and business opportunities of Malangan batik artisans are very prospective, but the manufacturing and marketing processes are not optimal. The implementation of the Community Partnership Program (PKM) focuses on the group of Home Industry Craftsmen (IRT) "Original Malangan Batik" and IRT Craftsmen "Sido Mukti Traditional Batik." This community service program is carried out to increase the amount of production efficiently by transforming technology. The addition of canting and electric stoves from the implementation of the Community Partnership Program (PKM) is one of the efforts to increase the amount of production efficiently by transforming technology. This community services aimed to improve the knowledge and skills of Conventional Malangan Batik entrepreneurs in Merjosari Kelurahan Malang in terms of bookkeeping, marketing of business results, and batik coloring, there is also bookkeeping training, marketing of business results and batik coloring. The training was held in one of the houses of residents of the Conventional Malangan Batik Group in Merjosari Village Malang, with a total of 30 participants. 


\section{Pendahuluan}

Batik telah menjadi salah satu budaya yang secara turun temurun telah diwariskan oleh nenek moyang dan telah ditetapkan oleh UNESCO sebagai budaya asli Indonesia. Setiap kota di Indonesia memiliki batik sesuai dengan ciri khas masing-masing, begitu juga dengan daerah Malang. Batik khas Malang biasa disebut Batik Malangan karena semua inspirasi motifnya adalah semua yang ada di Malang. Batik Malangan memang belum sepopuler batik yang ada di daerah Jawa lainnya, namun keindahaan Batik Malangan tidak kalah bagusnya dengan batik yang ada di daerah lain. Batik Malangan memiliki corak batik yang khas dan unik. Peminatnya umumnya dari pengunjung luar daerah Malang dan juga wisatawan mancanegara.

Jejak sejarah batik malang tidak ada yang mengungkap secara eksplisit tentang awal mula kemunculan batik serta budaya Batik Malang, namun jika merujuk pada berbagai macam kegiatan upacara tradisional pada abad ke XIX, akan banyak ditemui para pria dan wanita menggunakan medhang koro (hiasan kepala; udeng atau sewek) dengan motif batik sidomukti. Jika dicermati, kegiatan membatik ini merupakan budaya yang ditularkan oleh kerajaan mataram kuno saat menguasai kerajaan singosari pada tahun 1222 M. Batik malang atau juga biasa disebut Batik Malangan mempunyai tiga ciri utama yaitu, motif dasaran atau latar dari kain batik Malang berupa motif batik dari Candi Badut yang merupakan peninggalan kerajaan Kanjuruhan pada tahun 760 M (Pusat Komunikasi Publik, 2013).

Batik Malang berawal dari batik yang telah dipakai dalam upacara tradisional sejak abad XIX. Batik tersebut umumnya bermotif Sidomukti Malang dengan hiasan kotak putih di tengah yang biasa disebut Modhang Koro. Motif ini dipakai sebagai udheng (laki-laki) dan sewek (perempuan) dalam acara resmi untuk semua lapisan masyarakat. Batik Malangan memiliki tiga ciri pokok dan menjadi bagian dari tiga komponen pokok batik, yakni pertama pada tanahan atau dasar yang diambil dari motif batik di Candi Badut. Komponen kedua berupa motif pokok (hias isian) diisi dengan gambar Tugu Malang yang diapit oleh rambut singa pada sisi kiri dan kanannya sebagai lambang Kota Malang, serta komponen ketiga adalah motif hias untuk tumpal (pinggiran plus isen-isen) yang diisi tiga sulur yang membentuk sebuah rantai. Motif hias berupa sulur-sulur bunga yang dimaksudkan untuk menggambarkan Malang sebagai kota bunga (Sirait, 2018).

Motif batik Malang yang diketahui sekarang ini diantaranya adalah motif batik malang sawat kembang pring, kucecwara, celaket, dele kecer, kembang kopi, teratai singo, kembang juwet, kembang jeruk, kembang tanjung, kembang manggar, kembang mayang, dan kembang 
padma atau saat ini lebih dikenal dengan nama bunga teratai. Motif batik malang yang menjadi ciri khas tersebut dibuat berdasarkan ilustrasi candi-candi hindu peninggalan Kerajaan Kanjuruhan dari abad ketujuh. Salah satu motif batik malang yang paling populer diantara motif batik lainnya yaitu motif batik bunga teratai. Motif batik malang yang lain yaitu motif batik malang kucecwara. Motif batik tersebut mempunyai komposisi perpaduan motif diantaranya, Mahkota, gambar Tugu Malang, Rumbai Singa, Arca, Bunga Teratai, sulur-sulur juga isen-isen berbentuk belah ketupat (Rizky \& Anggun, 2018).
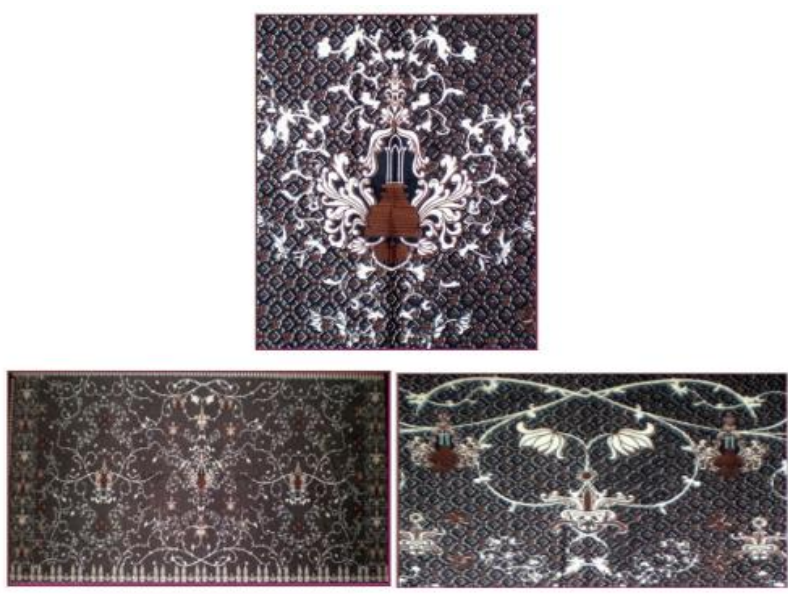

Gambar 1. Motif Batik Malang

Rencana usulan kegiatan Program Kemitraan Masyarakat (PKM) yang akan dilakukan oleh Tim pelaksana diarahkan untuk memberikan solusi alternatif terhadap beberapa permasalahan yang dihadapi oleh kelompok pengrajin batik tulis Malang agar dapat berkembang dan mampu bersaing. Berdasarkan hasil survei yang dilakukan oleh Tim pelaksana terhadap kondisi eksisting 2 kelompok Batik Konvensional di kelurahan Merjosari kota Malang, yaitu Pengrajin Industri Rumah Tangga (IRT) "Batik Asli Malangan” berlokasi di Jalan Joyo Asri Blok 12 No 215 Malang dan "Batik Tradisional Sido Mukti” berlokasi di Jalan Joyo Grand Gang 1 No. 11 Malang.

\section{Masalah}

Berdasarkan hasil observasi yang telah dilakukan sebelum melaksanakan kegiatan pengabdian, dapat ditemukan masalah yang dihadapi oleh kelompok pengrajin batik tulis Malang. Masalah pertama yang ditemukan adalah masih belum rapinya proses pencantingan yang dilakukan. Masalah kedua yang ditemukan yaitu masih terbatasnya peralatan yang digunakan sehingga mempengaruhi hasil produksi batik. Selain maslah teknis di atas, ditemukan pula malah dalam manajemen penjuan produk batik yang masih menggunakan metode manual door to door. 


\section{Metode}

\section{Solusi yang ditawarkan}

Permasalahan pada produksi solusi yang ditawarkan untuk menyelesaikan persoalan tersebut adalah pertama, pendekatan yang dilakukan untuk menyelesaikan masalah pengcantingan batik yang bentuk dan motifnya kurang halus dan bagus maka solusinya adalah dengan membuat alat yang mampu mempercepat proses pengcantingan dengan cepat dan baik. Untuk itu maka dibuat alat cetakan batik cap dari tembaga dan alat meja batik cap. Dengan cetakan batik cap menggunakan dari tembaga, maka motif batik yang akan dibuat dapat diselesaikan dengan mudah untuk dikerjakan dengan cepat dan mutu batik malangan lebih bagus. Kedua, pendekatan yang dilakukan untuk mengatasi masalah kekurangan peralatan manual batik yang memakan waktu lama dan mutu yang kurang, maka solusi yang dilakukan adalah dengan menambah peralatan manual batik yang mampu bekerja dengan cepat dan baik. Untuk itu solusinya adalah dengan menambah peralatan yaitu canting elektrik, kompor elektrik, bak pewarna, dan gawangan.

Pada permasalahan manajemen maka pendekatan yang ditawarkan untuk menyelesaikan persoalan adalah masalah sistem pemasaran konvensional dengan door to door bisa diselesaikan dengan membuat informasi produk yang mudah diakses oleh konsumen. Untuk itu solusi yang ditawarkan adalah dengan membuat informasi produk pemasaran berbasis brosur (Andi, 2016). Cara ini pada awalnya masih dibantu dengan cara pemasaran konvensional tapi tentunya dengan memberikan alamat pada brosur produk yang ditawarkan. Dengan demikian, maka konsumen dapat melihat dan mengikuti perkembangan jenis batik malangan serta harganya di brosur, maka konsumen akan lebih mudah untuk mendapatkan informasi produk dengan cepat. Serta, masalah pembukuan, pendekatan yang perlu dilakukan untuk menyelesaikan masalah ini adalah dengan membuat SOP (Standard Operating Prosedure) tentang Langkah-langkah dalam proses pembukuan (Dwipasari \& Subianto, 2017). Mitra diberi pemahaman dan dilatih cara melakukan pembukuan yang baik.

\section{Rencana Kegiatan}

Rencana kegiatan Program Kemitraan Masyarakat (PKM) yang berupa Langkahlangkah solusi untuk mengatasi masalah produksi dan manajemen yaitu pertama, koordinasi dan diskusi antar anggota tim dengan mitra (DIKTI, 2018). Hal ini dimaksudkan untuk mendapatkan masukan dan gagasan yang digunakan untuk implementasi program ini. Penyamaan persepsi dan langkah gerak dalam pelaksanaan program ini menjadi penting 
dengan cara kerja yang kolegial seluruh anggota tim dan mitra. Kedua, merancang alat beserta spesifikasinya, membuat dan sekaligus uji coba, yaitu: pembuatan alat cetakan batik cap dari tembaga, pembuatan alat meja batik cap, dan penambahan peralatan produksi batik malangan (Putri, et al, 2017). Ketiga, merancang dan membuat brosur yang memenuhi kriteria perancangan (Putri, et al, 2019). Keempat, pelatihan penggunaan dan pengelolaan pembukuan dan pemasaran kepada mitra (Ulliyawatik, 2017). Kelima, pembuatan panduan pembukuan. Keenam, pelatihan manajemen kendali mutu produk dan pembukuan keuangan (Sopanah, 2019).

\section{Hasil Dan Pembahasan}

\section{Aspek Produksi}

Tabel di bawah ini dapat dijelaskan bahwa kondisi mitra usaha masih belum maksimal memanfaat dan menggunakan alat yang mampu meningkatkan kinerja produksi batik malangan. Seperti yang tampak dalam Gambar 2, pekerja masih menggunakan cangting manual yang hasilnya masih kurang rapi dan memakan waktu yang sangat lama. Sedangkan, pada Gambar 2 menunjukkan aktivitas mitra 1 yang sudah memproduksi batik konvesional dengan peralatan manual tapi untuk mitra 1 sudah cukup banyak batik malangan yang diproduksi. Akan tetapi mitra 2 sama, semua peralatan manual, tetapi untuk kapasitas produksinya lebih sedikit.

Tabel 1 Kondisi Aspek Produksi Mitra

\begin{tabular}{|r|l|l|l|}
\hline No. & \multicolumn{1}{|c|}{ Uraian } & \multicolumn{1}{|c|}{$\begin{array}{c}\text { IRT “Batik Asli Malangan” } \\
\text { (Mitra 1) }\end{array}$} & \multicolumn{1}{|c|}{$\begin{array}{c}\text { IRT "Batik Tradisional Sido } \\
\text { Mukti” (Mitra 2) }\end{array}$} \\
\hline 1 & Nama bahan baku & Kain batik mori, dll. & Kain batik mori, dll. \\
\hline 2 & Asal & $\begin{array}{l}\text { Malang kelurahan Merjasari } \\
\text { Lowokwaru }\end{array}$ & $\begin{array}{l}\text { Malang kelurahan Merjasari } \\
\text { Lowokwaru }\end{array}$ \\
\hline 3 & Lama Usaha & 10 Tahun & 5 Tahun \\
\hline 4 & Peralatan Produksi & Sudah ada manual & Sudah ada manual \\
\hline 5 & Jenis Peralatan & Semua alat masih manual & Semua alat masih manual \\
\hline 6 & Bahan Pewarna & Ada, Sintetis & Ada, Sintetis \\
\hline 7 & Dingklik/bangku & Ada terbatas & Ada terbatas \\
\hline 8 & Bandul & Ada manual & Ada teratas \\
\hline 9 & Taplak & Ada & Ada \\
\hline 10 & Cangting & Ada manual & Ada manual \\
\hline 11 & Meja kayu & Sudah ada manual & Sudah ada manual \\
\hline 12 & Lilin/malam & Ada & Ada \\
\hline 13 & Wajan dan Kompor & Ada terbatas & Ada terbatas \\
\hline
\end{tabular}




\begin{tabular}{|r|l|l|l|}
\hline 14 & Gawangan & Ada terbatas & Ada terbatas \\
\hline 15 & Metode Pengerjaan & Sudah terampil manual & Belum terampil manual \\
\hline 16 & Tenaga kerja & 2orang & 1 orang \\
\hline 17 & Kapasitas produksi & $\begin{array}{l}50 \text { s/d 60 Batik malangan } \\
\text { Dalam 1 bulan }\end{array}$ & $\begin{array}{l}\text { 20 s/d 30 batik malangan } \\
\text { Dalam 1 bulan }\end{array}$ \\
\hline
\end{tabular}

Catatan: *) Data disusun berdasarkan hasil survei yang dilakukan oleh Yatimah (2020)

Beberapa contoh produk batik yang telah dihasilkan terdapat pada, Gambar 2, menunjukkan bahwa diperlukan penggunaan alat yang mampu meningkatkan produktivitas dan mutu batik.
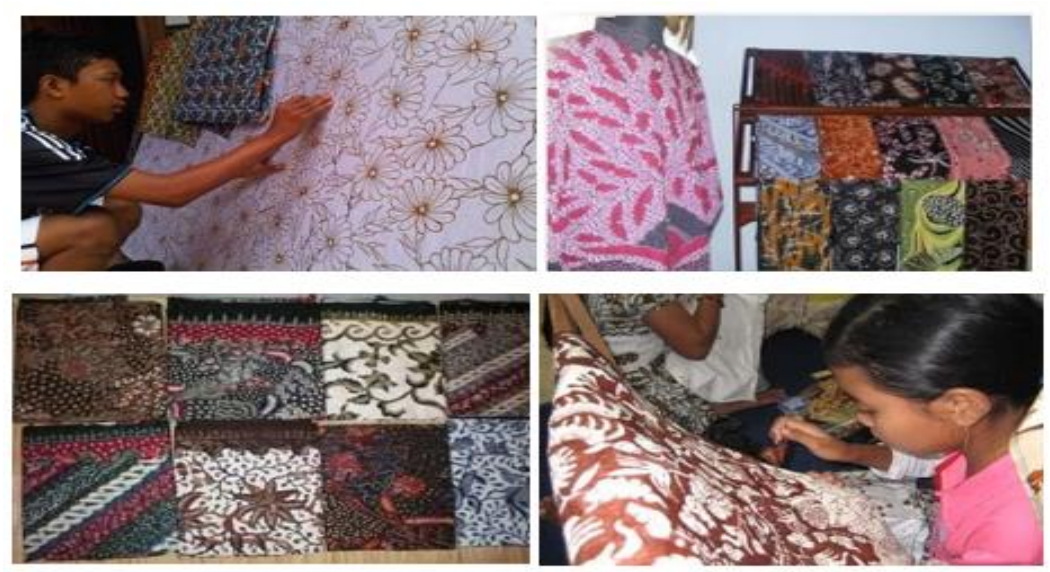

Gambar 2. Aktivitas, Proses, dan Hasil Batik Malangan

\section{Proses Produksi}

Berdasarkan pengalaman pengrajin batik malangan rata-rata dapat memproses 20-50 buah batik untuk pengrajin IRT "Batik Asli Malangan" dan 10-30 buah batik untuk pengrajin IRT "Batik Tradisional Sido Mukti". Jumlah bahan baku bambu yang diproses setiap hari sangat bervariasi dan tidak bisa diprediksi secara pasti karena proses pembuatan batik malangan tergantung pada pesanan. Tenaga kerja yang terlibat selama proses produksi adalah 2 orang pada pengrajin IRT "Batik Asli Malangan" dan 1 Orang untuk Pengrajin IRT "Batik Tradisional Sido Mukti”. Proses produksi pada masing-masing pengrajin memiliki kesamaan. Alur produksi batik malangan dijelaskan sebagai berikut:

1. Kain mori/batik dipersiapkan untuk diproses.

Kain batik/mori, kain mori adalah kain tenun benang kapas hasil olahan pabrik dengan anyaman polos dan diputihkan. Kain mori mempunyai ketebalan, kehalusan, dan kerapatan kain yang pas, sehingga seringkali dibuat untuk membatik sama seperti kainkain pada umumnya, kain mori memiliki beberapa tingkatan kualitas, tergantung kualitas 
benang tenun dan kerapatan anyaman.

\section{Penyorekan}

Nyorek atau memola adalah proses menjiplak atau membuat pola di atas kain mori dengan cara meniru pola motif yang sudah ada, atau biasa disebut dengan ngeblat. Pola biasanya dibuat di atas kertas roti terlebih dahulu, baru dijiplak sesuai pola di atas kain mori. Tahapan ini dapat dilakukan secara langsung di atas kain atau menjiplaknya dengan menggunakan pensil atau canting. Namun agar proses pewarnaan bisa berhasil dengan baik, tidak pecah, dan sempurna, maka proses batikannya perlu diulang pada sisi kain dibaliknya. Proses ini disebut ganggang.

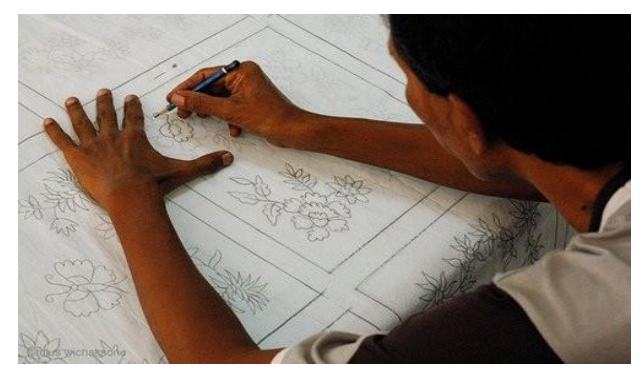

Gambar 3. Proses Penyorekan

\section{Pencantingan}

Pertama, gambar pola motif batik yang telah ditentukan dengan pensil. Sebenarnya langsung nyanting dengan malam sih tidak apa-apa kak, tapi berhubung aku masih pemula jadi harus pake pensil biar waktu dicantingnya nanti rapi. setelah sudah digambar semua motifnya, hidupkan kompornya dengan api kecil saja lalu panaskan malam di atas wajan sampai malam cair. Tetapi jangan terlalu cair sekali ya kak, bisa-bisa nanti hasilnya saat dicanting bisa meleber ke mana-mana. Usahakan saat dicanting, malamnya tembus ke bagian belakang kainnya. Menyanting ini adalah bagian yang tersulit, dan hati-hati sama proses pencantingan ini soalnya malam yang panas ini bisa melukai.

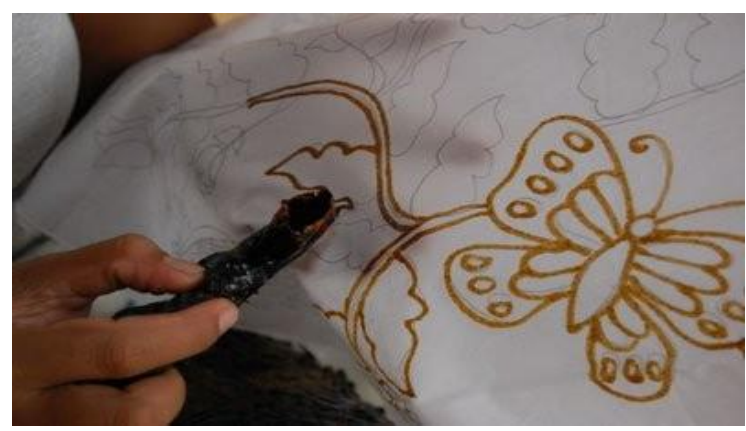

Gambar 4. Proses Pencantingan/Pembatikan 


\section{Nembok}

Nembok yaitu proses menutupi dengan lilin malam bagian-bagian yang akan tetap berwarna putih (tidak berwarna). Canting untuk bagian halus, atau kuas untuk bagian berukuran besar. Tujuannya adalah supaya saat pencelupan bahan ke dalam larutan pewarna, bagian yang diberi lapisan lilin tidak terkena.

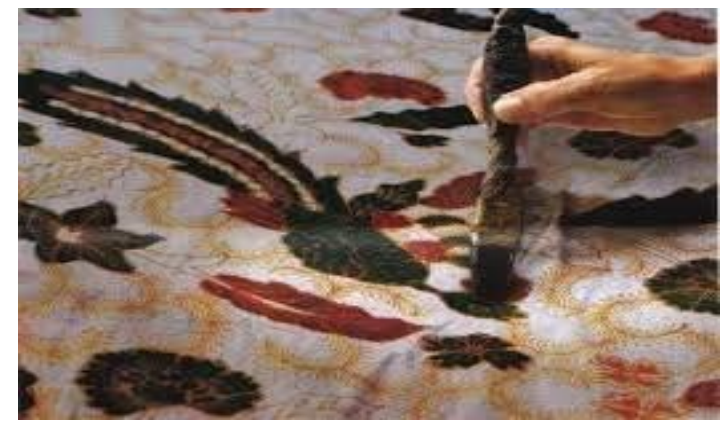

Gambar 5. Proses Penembokan

5. Perendaman dan Pewarnaan

Proses pencelupan kain yang sudah dibatik ke cairan warna secara berulang-ulang sehingga mendapatkan warna yang diinginkan. Dalam proses pemberian warna terdapat istilah nyoga yaitu proses pencelupan/pewarnaan untuk mendapatkan warna coklat. Sama dengan proses nembok, semakin banyak warna yang akan dibuat proses medel-pun juga akan semakin sering. Proses pencelupan kain yang sudah dibatik ke cairan warna secara berulang-ulang sehingga mendapatkan warna yang diinginkan. Dalam proses pemberian warna terdapat istilah nyoga yaitu proses pencelupan/pewarnaan untuk mendapatkan warna coklat. Sama dengan proses nembok, semakin banyak warna yang akan dibuat proses medel-pun juga akan semakin sering.

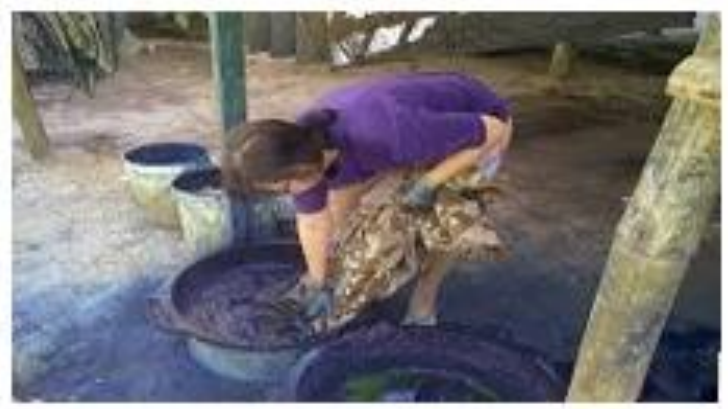

Gambar 6. Proses Pewarnaan

\section{Pengerokan}

Pengerokan adalah proses menghilangkan lilin/malam menggunakan alat penggerok yang biasanya terbuat dari lempengan logam. Setelah dilakukan pengerokan, beberapa motif 
dilanjutkan dengan proses mbironi, yaitu menutup bagian-bagian tertentu dengan malam agar tidak terkena warna pada proses pewarnaan berikutnya. Proses nembok medel dan ngerok adalah satu kesatuan dalam pembentukan warna yang diinginkan oleh si pembatik. Semakin banyak warnanya akan semakin sering 3 proses tersebut berulang.

\section{Proses pelorotan}

Proses selanjutnya adalah nglorot, kain yang telah berubah warna direbus air panas. Tujuannya adalah untuk menghilangkan lapisan lilin, sehingga motif yang telah digambar sebelumnya terlihat jelas. Anda tidak perlu khawatir, pencelupan ini tidak akan membuat motif yang telah Anda gambar terkena warna, karena bagian atas kain tersebut masih diselimuti lapisan tipis (lilin tidak sepenuhnya luntur). Setelah selesai, maka batik tersebut telah siap untuk digunakan.

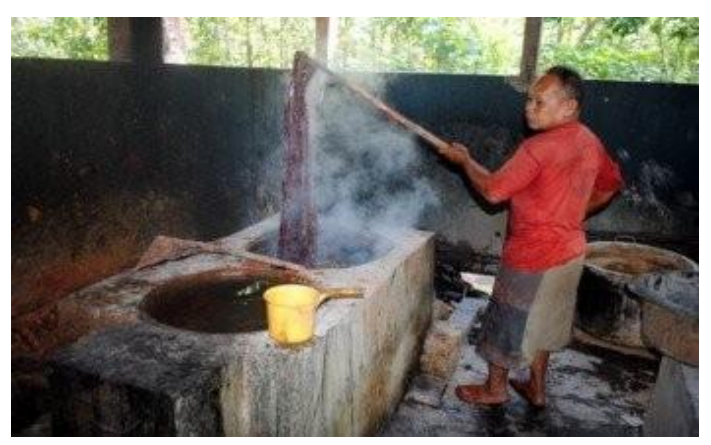

Gambar 7. Proses Pelorotan

\section{Aspek Manajemen}

Aspek manajemen, kondisi mitra secara garis besar juga masih sangat sederhana dan konvensional sehingga kemampuan untuk mengembanggkan usaha yang lebih besar masih sulit untuk dicapai. Secara rinci, kondisi mitra adalah sebagaimana terdapat pada Tabel 2.

Tabel 2. Kondisi Aspek Manajemen Mitra

\begin{tabular}{|c|l|l|l|}
\hline No. & \multicolumn{1}{|c|}{ Aspek kondisi } & \multicolumn{1}{|c|}{ IRT “Batik Asli Malangan” } & \multicolumn{1}{c|}{$\begin{array}{c}\text { IRT "Batik Tradisional Sido } \\
\text { Mukti" }\end{array}$} \\
\hline 1 & Lama Usaha & 10 Tahun & 5 Tahun \\
\hline 2 & Stok Bahan baku & Stok yang dimiliki terbatas & Stok yang dimiliki sangat terbatas \\
\hline 3 & Cara Pembuatan & Dibuat berdasarkan pesanan & Dibuat berdasarkan pesanan \\
\hline 4 & Pengemasan & Belum ada & Belum ada \\
\hline 5 & Keberadaan user manual & Belum ada user manual & Belum ada user manual \\
\hline 6 & $\begin{array}{l}\text { Cara pemasaran dan } \\
\text { promosi }\end{array}$ & Konvensional dan mood to mood & Konvensional dan mood to mood \\
\hline 7 & Kendali mutu & Masih belum di lakukan dengan baik & Masih belum di lakukan \\
\hline 8 & Permodalan & Sudah ada tapi sangat terbatas & Tidak punya modal yang cukup \\
\hline 9 & Pembukuan keuangan & Belum dilakukan secara baik & Belum dilakukan \\
\hline
\end{tabular}


Kondisi aspek manajemen yang dilakukan Mitra secara operasional di lapangan adalah sebagai berikut:

a. Sistem pemasaran yang dilakukan masih dengan cara konvensional dengan mood to mood menawarkan ke penduduk desa maupun kota secara langsung. Setelah mendapatkan pesanan baru dibuatkan sesuai dengan banyaknya pesanan atau datang langsung ke tempat produksi. Waktu yang dibutuhkan untuk menawarkan batik Malangan lebih banyak dan tidak efektif.

b. Tidak ada sistem stok batik Malangan yang banyak, sehingga ketika ada pemesanan yang bersamaan maka dengan jumlah yang banyak maka sering terjadi keterlambatan produksi sehingga penyerahan batik pesanan menjadi sering terlambat.

c. Masalah kendali mutu produk masih belum ada dengan baik, sehingga beberapa produk ketika diserahkan pada konsumen masih ada motif batik yang pecah dan dikomplain oleh konsumen. Produk batik Malangan juga yang membutuhkan pencantingan yang baik akan digunakan pencantingan cap yang kuat sehingga dapat menghasilkan batik Malangan yang tidak mudah pecah dan bagus.

d. Tidak ada pembukuan yang tertib dan disiplin dari hasil penjualan tersebut sehingga tidak bisa diketahui dengan jelas seberapa besar untungnya. Kondisi hal tersebut juga tidak bisa terlepas dari adanya tidak terpisahnya antara keuangan usaha dengan kebutuhan keluarga.

Dari tabel 2 di atas terlihat bahwa secara manajemen masih banyak hal yang belum dilakukan, baik itu yang menyangkut manajemen bahan baku, manajemen pemasaran, maupun manajemen keuangan. Pemasaran masih menggunakan cara konvensional dengan menawarkan cara mood to mood, dan cara ini sangat menghabiskan waktu. Sedangkan dari aspek keuangan, masih belum dilakukan pembukuan yang rapi. Hal ini tidak terlepas dari kondisi finansial keluarga yang masih tidak bisa membedakan antara keuangan dari hasil usaha dengan kebutuhan keluarga sehari hari.

\section{Potensi dan Peluang Bisnis}

Potensi dan peluang bisnis pengrajin batik Malangan ini sangat prospektif. Setiap tahun banyak konsumen dari dalam maupun dari luar Kota Malang, terutama sekolah-sekolah dan perkatoran yang sudah menerapkan pemakaian batik, selalu mencari batik Malangan sampai ke tempat-tepat produksi batik di Malang. Hal ini terkait dengan motif batik Malangan yang 
selalu menyuguhkan motif-motif batik malangan yang disukai oleh konsumen. Sementara itu, kebutuhan akan batik malangan ini masih belum bisa dipenuhi semua terutama jenis dan motif-motif batik yang baru yang mampu memberikan sentuhan inovasi dan kreatif sehingga menarik konsumen.

Fakta menunjukkan bahwa saat ini pesanan batik Malangan terus berkembang dengan membutuhkan banyak batik. Jumlah sekolah-sekolah yang membutuhkan batik untuk siswanya sangat banyak dan terus berkembang terutama di perkotaan. Hampir disetiap daerah di wilayah Malang terdapat sekolah-sekolah dan perkatoran yang memerlukan batik. Dari sini, maka potensi untuk pemasaran batik malangan menjadi sangat potensial dan bisa dikembangan sebagai usaha yang mempunyai peluang yang cukup bagus.

\section{Pembuatan Cetakan Batik Cap, Meja Batik Cap dan Bak Pewarna}

Cetakan batik cap, hal ini terbuat dari lempengan tembaga yang bisa bertahan tiga sampai dengan lima tahun (3 s.d 5 tahun). Ukuran cetakan adalah $20 \mathrm{~cm} \times 20 \mathrm{~cm}$ dan dibuat dari bahan tembaga, sesuai dengan namanya cara membuatnya di Cap.

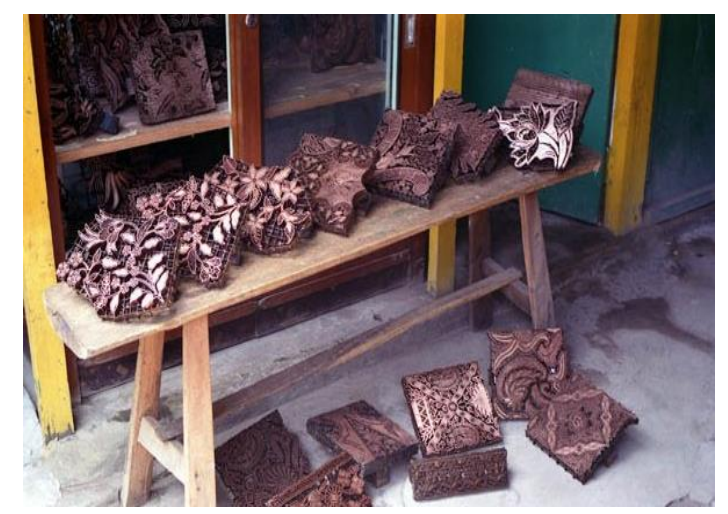

Gambar 8. Cetakan Batik Cap

Cetakan itu sendiri merupakan design motif yang akan dicap pada kain batik, hasil yang didapat dengan metode ini hampir mirip dengan batik tulis. Hasilnya tembus akan tetapi masih di bawah kualitas batik tulis tembusnya. Untuk kontras warna tidak diragukan lagi, hasil warna untuk batik cap sendiri sangat terang, tidak mudah luntur. Proses pembuatan cetakan batik cap ini memerlukan waktu sekitar satu mingguan, proses penjemuran dan proses pengecapan sangat berpengaruh terhadap hasil akhir sebuah Batik Cap. Kesannya memang mudah, akan tetapi sangat sulit sekali untuk diimplementasikan. 


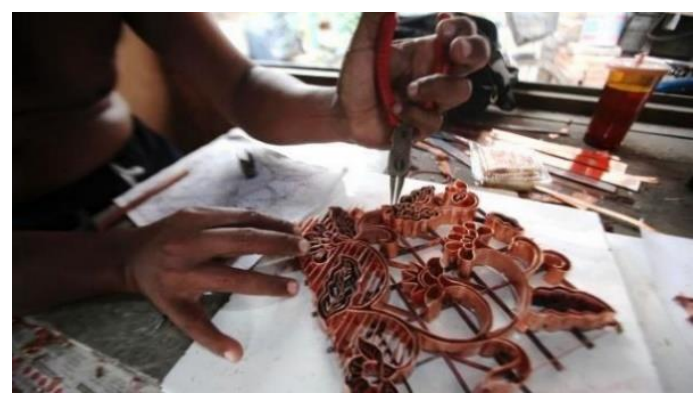

Gambar 9. Proses Pembuatan Cetakan Batik Cap

Kemudian, di samping cetakan batik cap sebagai alat batik cap, maka diperlukan sarana untuk mengecap batik tersebut, yaitu meja cap. Meja cap yang digunakan dalam membuat batik cap terbuat dari kayu, dengan rangkaian alat meja batik cap memiliki spesifikasi sebagai berikut: (1) Papan kayu 200 cm x 100 cm; (2) Spon/busa; (3) Kayu 45; (4) Triplek; (5) Plastik bening ; (6) Kayu meja; (7) Plastik perlaku; dan (8) Kaki meja tinggi meja dibuat sedemikian rupa sehingga orang yang mencap dapat bekerja dengan baik dan nyaman. Permukaan meja cap dilapisi dengan kasur/busa, kain blacu dan kain serak tipis. Kasur terbuat dari spon/busa, setebal kurang lebih $10 \mathrm{~cm}$ dan dibuat rata agar hasil pengecapan bagus. Kain blacu berukuran lebih besar sedikit dari meja atau kasur, yang digunakan untuk menutup bagian atas kasur. Kegunaannya untuk menjaga agar pada waktu pengecapan malam yang mungkin menembus kain, tidak langsung kena kasur. Kain serak tipis ukurannya sama dengan kain blacu. Kain ini yang terletak di bagian dalam dan selalu dalam keadaan lembab (diseka dengan larutan soda abu).

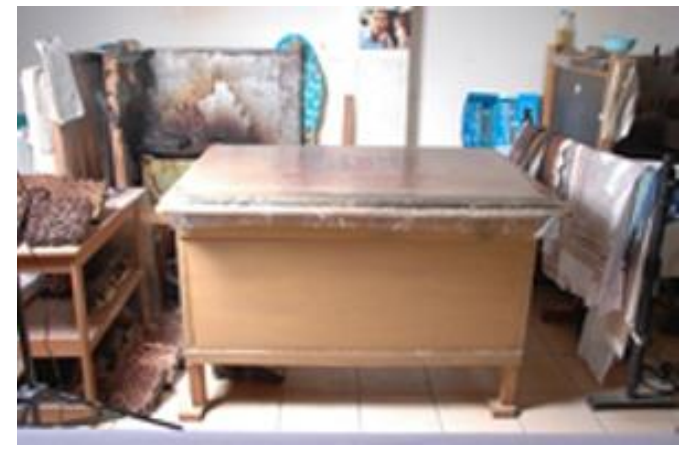

Gambar 10. Meja Batik Cap

Selanjutnya, alat yang digunakan dalam proses pembuatan batik cap adalah bak pewarna. Penggunaan bak pewarna yaitu, kalau sudah selesai di cap, kain tersebut dirapikan, ditumpuk dan dilipat dan memasuki ruang tunggu pewarnaan. Ini tempat pewarnaan, ada beberapa bak yang di dalamnya berisi air berwana dan berbeda-beda tiap bak-nya. 


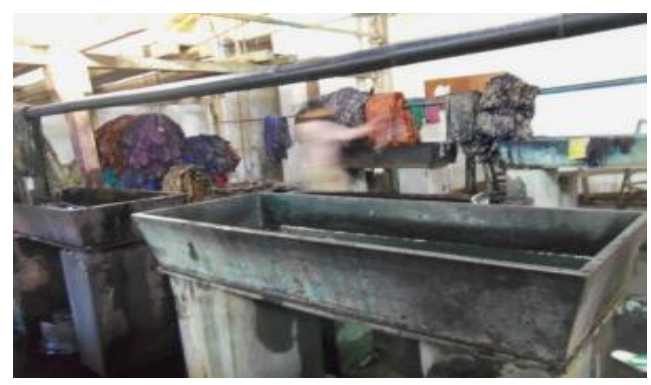

Gambar 11. Bak Pewarna

Adapun proses pencapuran bahan pewarna pada masing-masing bak pewarna adalah sebagai berikut:

a. Bak pertama terdiri atas: Naptol 10gram, TRO 5 gram, dan air panas 1,5. Costic Soda 5 gram dicampur ke dalam air 1,5 lt, dengan memasukan costic soda dan TRO ke dalam air hangat hingga larut, kemudian naptol dicampurkan kedalamnya sampai larut.

b. Bak kedua terdiri atas: air dingin 1,5 lt, garam 20 gram. Masukkan garam ke dalam air dingin dan diaduk sampai rata.

c. Bak ketiga terdiri atas: air dingin \pm 2 liter dan larutan Fixanol $\pm 10 \mathrm{ml}$. masukkan Fixanol ke dalam air dan aduk sampai rata. Bak ketiga berfungsi sebagai penguat atau pengunci warna.

d. Bak keempat terdiri atas air \pm 5 liter, berfungsi sebagai pembilas.

Sedangkan proses pewarnaan pada kain adalah sebagai berikut:

a. Sebelum memasuki tahap pencelupan, kain harus diberi motif dengan teknik ikat atau jumput. Teknik ikat/jumput disesuaikan dengan kreativitas masing-masing. Jadi, motif pada kain disesuaikan dengan keinginan pembatik.

b. Setelah proses pemberian motif selesai, masukkan kain ke dalam bak pertama. Lalu tiriskan.

c. Kemudian, masukkan ke dalam bak kedua yang berisi zat warna, tiriskan.

d. Pada tahap selanjutnya, masukkan ke dalam bak ketiga yang berisi larutan fixanol sebagai pengikat warna agar warna tidak cepat memudar, lalu tiriskan.

e. Tahap terakhir, masukkan kain pada bak keempat untuk dibilas. Jemur kain dengan tidak terkena matahari secara langsung (cukup terkena angin).

f. Ikatan pada kain dapat dilepas agar dapat mengetahui hasil motif yang sudah dibuat.

Pelaksanaan ipteks bagi masyarakat (IbM) pada kelompok Pengrajin Industri Rumah Tangga (IRT) "Batik Asli Malangan" dan Pengrajin IRT "Batik Tradisional Sido Mukti” ini 
dilaksanakan dengan memberikan bantuan seperangkat alat cetakan batik cap, meja batik cap dan bak pewarna. Pembelian alat tersebut dilakukan di produsernya langsung yaitu di Malang. Sedangkan model, warna dan lainnya di koordinasikan dengan mitra.

\section{Penambahan Canting Elektrik, Gawangan, dan Kompor Elektrik}

Canting untuk membatik adalah alat kecil yang terdiri dari gagang/tangkai terbuat dari bambu, nyamplungan/badan canting (tempat cairan lilin) dan carat/cucuk (tempat keluarnya lilin waktu membatik) yang terbuat dari tembaga. Canting ini dipakai untuk menuliskan pola Batik dengan cairan lilin (malam). Menurut fungsinya ada canting reng-rengan (untuk membatik reng-rengan batikan pertama sesuai pola atau tanpa pola) dan canting isen (untuk membatik isi bidang). Menurut besar kecil cucuk ada cucuk kecil, sedang dan besar. Menurut banyaknya cucuk ada canting cecekan/cucuk satu, canting loron/cucuk dua, canting telon/cucuk tiga, canting prapatan/cucuk empat, canting liman/cucuk lima, canting byok/cucuk tujuh atau lebih dan canting renteng/galaran (bercucuk genap tersusun dari atas ke bawah).

Seiring perkembangan jaman kini tengah dikembangkan inovasi baru berupa canting elektronik. Canting elektronik ini terdiri dari tiga bagian utama, yakni bak penampung lilin batik atau malam, tangkai pemegang, dan alat kontrol suhu yang berfungsi mengontrol suhu canting. Salah satu kelebihan lain, paruh canting bisa dicopot dan diganti sesuai ukuran yang diinginkan. Seluruh jenis paruh canting, yakni ceceg, klowong, tembogan, dobel ceceg, dan dobel klowong bisa dipasang di tubuh canting. Padahal pada canting tradisional, lima jenis ini terpisah-pisah.

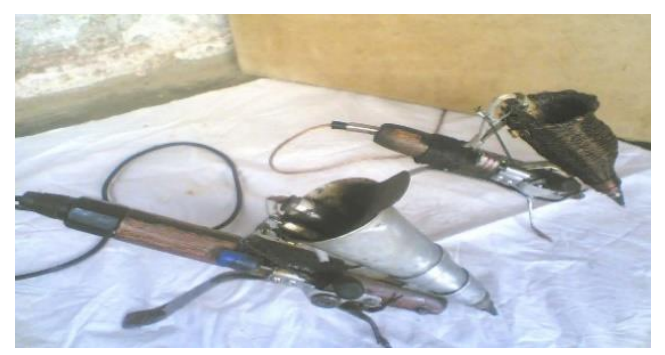

Gambar 12. Canting Elektrik

Canting elektrik ini membuat batik tulis menjadi sangat mudah, tanpa harus telaten, tanpa harus hati-hati, penggunaanya sangat mudah layaknya seperti kita menulis menggunakan spidol atau pulpen saja. Canting ini dilengkapi dengan tuas pengatur keluarnya malam/cat dan mata cantingnya dapat di ganti ganti sesuai kebutuhan saat bekerja (dapat dilakukan saat sedang dipakai, malam/cat tidak akan tumpah karena ada klep/katup penahan Malam/cat). 
Kain batik yang indah dan menarik tentun tidak terlepas dari bagaimana kelihaian tangantangan pengrajin dalam mengolahnya. Berbagai macam cara dapat dilakukan untuk menciptakan karya seni tradisional ini dan tentunya dengan keuletan dalam menggunakan teknik-teknik tradisional alami yang mampu menghasilkan kain batik dengan ceceg-ceceg yang membentuk suatu pola motif indah akan membuat nilai dari batik tersebut menjadi tinggi dibandingkan dengan pembuatan batik menggunakan teknik moderen seperti cap, printing, sablon, dan sebagainya. Dalam pembuatannya batik tradisional ada beberapa perlengkapan yang harus dipersiapkan, diantaranya adalah gawangan.

Gawangan adalah alat bantu membatik yang berbentuk gawang dengan dua kaki di kanan dan kiri yang berfungsi sebagai peyanggaa sebuah pilar atau bilah. Tinggi gawangan $50 \mathrm{~cm}$ dan panjang bilah $1 \mathrm{~m}$. Gawangan ini terbuat dari bahan kayu. Fungsi utama gawangan yaitu sebagai tempat untuk menaruh kain yang akan diberi pola batik.

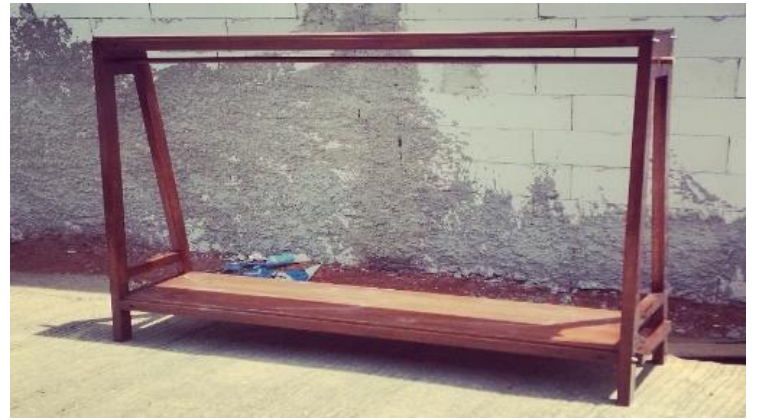

Gambar 13. Gawangan

Agar budaya batik tetap lestari dan semakin menarik, diperlukan inovasi, baik dalam desain maupun teknologi proses pembuatannya. Salah satu alat terpenting dalam proses pembuatan batik adalah kompor. Sebelumnya masyarakat membatik menggunakan kompor minyak tanah, sehingga kestabilan panas kurang terjaga. Kompor elektrik hadir untuk memecahkan masalah itu. Setelah bagian kain tertutup "malam" dengan sempurna, maka proses melukiskan motif batik sesuai selera dengan "canting" di kain semakin mudah. Agar proses mencairkan "malam" berjalan stabil, maka membutuhkan kompor dengan suhu panas yang stabil pula.

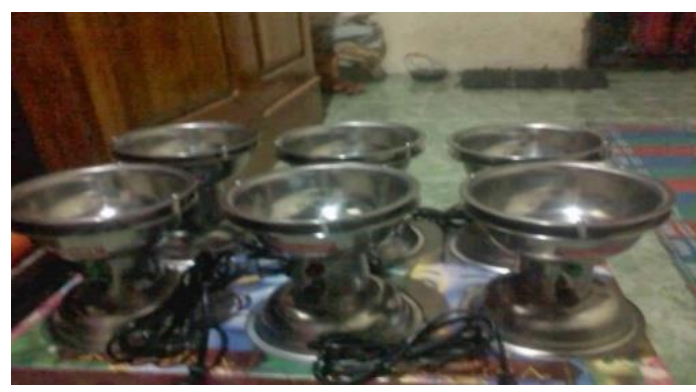

Gambar 14. Kompor Elektrik 
Perlu transformasi teknologi khususnya di bidang perbatikan karena sangat dibutuhkan oleh para perajin batik malangan, maka tercetuslah ide bagaimana cara menambah jumlah produksi secara efisien dengan mentransformasi teknologi. Penambahan canting dan kompor elektrik dari pelaksanaan ipteks bagi masyarakat $(\mathrm{IbM})$ ini menjadi salah satu upaya untuk menambah jumlah produksi secara efisien dengan mentransformasi teknologi tersebut.

\section{Partisipasi Mitra}

Bentuk partisipasi mitra dalam pelaksanaan program ini yaitu Mitra turut serta dalam diskusi dan memberikan informasi tentang berbagai persoalan dan menyampaikan kesulitan yang dihadapi dalam proses pembuatan alat cetakan batik cap dari tembaga dan meja batik cap maupun manajemennya; Memberikan masukan dalam proses pembuatan alat maupun peralatan lainnya sehingga luaran yang dihasilkan program ini benar-benar bermanfaat dan sesuai dengan harapan mitra; ikut menyiapkan sarana dan prasarana dalam uji coba alat yang telah dihasilkan Bersama-sama dengan anggota tim; mengikuti pelatihan dan tutorial yang diadakan sehingga mengerti tentang aspek produksi dan manajemen, baik itu tentang penggunaan pembukuan; dan bersedia bekerja sama dengan tim secara berkelanjutan bilamana diperlukan.

\section{Kesimpulan}

Berdasarkan uraian hasil dan pembahasan, maka dapat ditarik kesimpulan bahwa motif batik malangan mengharapkan adanya suatu keluhuran dari pemakainya untuk selalu berdiri tegak, berani, bertanggung jawab dengan penuh rasa hormat agar mampu menyatu dengan lingkungan dia tinggal; Potensi dan peluang bisnis pengrajin batik malangan ini sangat prospektif. Setiap tahun banyak konsumen dari dalam maupun dari luar Kota Malang, terutama sekolah-sekolah dan perkatoran yang sudah menerapkan pemakaian batik, selalu mencari batik malangan sampai ke tempat-tepat produksi batik di Malang; Pelaksanaan pengabdian masyarakat pada kelompok Pengrajin Industri Rumah Tangga (IRT) "Batik Asli Malangan" dan Pengrajin IRT "Batik Tradisional Sido Mukti” ini dilaksanakan dengan memberikan bantuan seperangkat alat cetakan batik cap, meja batik cap, dan bak pewarna. Pembelian alat tersebut dilakukan di produsennya langsung yaitu di Malang. Sedangkan model, warna dan lainnya dikoordinasikan dengan mitra; perlu transformasi teknologi khususnya di bidang perbatikan karena sangat dibutuhkan oleh para perajin batik malangan, maka tercetuslah ide bagaimana cara menambah jumlah produksi secara efisien dengan 
mentransformasi teknologi. Penambahan canting dan kompor elektrik dari pelaksanaan pengabdian masyarakat ini menjadi salah satu upaya untuk menambah jumlah produksi secara efisien dengan mentransformasi teknologi tersebut; dalam rangka peningkatan pengetahuan dan keterampilan pengusaha Batik Malangan Konvensional di Kelurahan Merjosari Malang dalam hal pembukuan, pemasaran hasil usaha dan pewarnaan batik, pengabdi dan anggota pengabdi dalam rangka pelaksanaan Program Kemitraan Masyarakat (PKM) Kelompok Batik Malangan Konvensional di Kelurahan Merjosari Malang mengadakan pelatihan pembukuan, pemasaran hasil usaha dan pewarnaan batik; Pelatihan dilaksanakan di salah satu rumah warga Kelompok Batik Malangan Konvensional di Kelurahan Merjosari Malang dengan jumlah peserta 30 orang pelaku usaha.

\section{Ucapan Terima Kasih}

Ungkapan terima kasih penulis ucapkan kepada Ketua Sekolah Tinggi Ilmu Ekonomi Muhammadiyah Palopo dan Ketua P3M Sekolah Tinggi Ilmu Ekonomi Muhammadiyah Palopo yang telah mewadahi penulis dalam melaksanakan program pengabdian masyarakat.Serta kepada Aparat Desa Pombakka dan ibu-ibu PKK Kecamatan Malangke BaratKabupaten Luwu Utara yang telah memberikan kerjasama yang baik sehingga kegiatan pengabdian Kuliah Kerja Nyata Pembelajaran Pemberdayaan Masyarakat (KKN-PPM) ini terlaksana dengan baik sesuai dengan waktu/jadwal pelaksanaan yang telah ditentukan sebelumnya berkat dukungan dana dari STIE Muhammadiyah Palopo Tahun 2018.

\section{Daftar Pustaka}

Andi Normaladewi. 2016. The Role of Industrial Environment and Innovation PhenomenonAnalysis in the Development of Batik Small and Medium-sized Enterprises in Malang and Batu. Jurnal Ekonomi Bisnis, 21 (1).

C F Putri, I Nugroho, D Purnomo. 2019. Performance Measurement of SMEs of Malang Batik as a Result of Local Wisdom with Balanced Scorecard. IOP Publishing. Materials Science and Engineering 505 (2019) 012022. doi:10.1088/1757899X/505/1/012022.

Chauliah Fatma Putri, Adya Hermawati, Dwi Purnomo. 2017. Pengaruh Karakteristik Individu Dan Kewirausahaan Terhadap Kinerja Ikm Batik di Malang Raya. Seminar Nasional dan Gelar Produk.

Direktorat Penelitian dan Pengabdian kepada Masyarakat, DIKTI. 2018. Panduan Pelaksanaan Penelitian Dan Pengabdian Kepada Masyarakat Di Perguruan Tinggi Edisi XII. 
Lita Dwipasari dan Totok Subianto. 2017. Pendampingan Pengembangan Kub (Kelompok Usaha Bersama) Batik Malangan Di Kota Malang. Jurnal ABDIMAS Unmer Malang, $2(2)$.

Pusat Komunikasi Publik. 2013. Kina: Karya Indonesia - Edisi Khusus 2013. Jakarta: Kementrian Perindustrian.

Rizky, Destantri Anggun. 2018. Analisis Perbaikan Kualitas Pada Batik tulis Malang Dengan Menggunakan Metode Taguchi. Thesis. Universitas Brawijaya.

Sirait, M. 2018. Cleaner production options for reducing industrial waste: the case of batik industry in Malang, East Java-Indonesia. The 4th International Seminar on Sustainable Urban Development. IOP Publishing. Earth and Environmental Science 106 (2018) 012069. doi :10.1088/1755-1315/106/1/012069.

Sopanah, Syamsul Bahri, Mohammad Ghozali. 2019. Ekraf Batik Malang Berbasis Kearifan Lokal. Conference on Innovation and Application of Science and Technology.

Ulliyawatik. 2017. Application of Comprehensive Budget Preparation on Umkm Batik Malang (Study at UMKM Batik Blimbing - Malang). Jurnal Manajemen Bisnis, 7 (1). 